\section{TREATMENT OF INFLUENZA.}

To the Editor of The Indian Medical Gazeite:

SIR - The undoubted virtue of the drug thymol in curing catarrh of the air passages has led me to use it along with guaiacol in the treatment of pneumonia in the recent epidemic, and I am glad to inform the medical proepiden that these two drugs combined exert a distinct fession that these two drugs combined exert a distinct influence in checking the progress of the disease. Three minims of pure guaiacol and 3 grains of thymol to be dissolved in $1 \mathrm{dr}$. of spirit ammon. aromat. or rectified spirit; 6 drs. of syrup tolu to be added, and to be diluted spirit; 6 drs. of syrup tolu to with 3 oz. of water: One-sixth part This mixture gradually be administered every 4 hours. This mixture gradually brings down the high temperature and checks the inflammatory process undoubtedly, by causing destruction of the germs. The bronchial secretions dry up and impediment germs. The bronchial secrion is removed. Strychnia and to circulation and respiration is removed. digitalis should always be used as an adjunct where there is cardiac weakness. I gave extensive trials of this mixture in many very serious cases in the Ram Krishna Home
of Service,. Benares, and 90 per cent. cases were discharged cured.

Yours, etc.,

N. C. MOITRA, м.в.

Houz Katra, Benares City :

Sth August, 1919.

HYDROGEN PEROXIDE IN CHOLERA.

To the Editor of THE INDIAN MEDICAL GazeTte. SIR-In the therapeutic notes published by Parke, Davis and Co., I wrote a short note on "Hydrogen PeroDavis and Co., I wrote a Cholera." Therein I mentioned xide in the treatment of the hation in administration of Asiatic cholera. Since then I have conthe true type of Asiatic cholera. Since then I have continued using this drug in the treatment of cholera with good results, and I again brought it to the notice of the general public by publishing my successful cases in the "Ieader," of Allahabad, in June 1918, and the curative value of this drug. Thinking that this publication would not reach medical men, I venture to write to your esteemed journal and I sincerely hope not in vain. Four to six doses of the mixture given below will speedily check the vomiting and purging and will canse also improvement in the pulse very soon. I generally prescribe tincture podophyllin, in half-drop doses every 3 hours afterwards, just to stimulate the liver every 3 hours afterwards of the stem of the plantain tree ar welps much in establishing the urinary flow. The mixture I generally prescribe is fresh hydrogen peroxide 3 drams and aqua destl. 2 ounces one-sixth part of this to be given every hour until purging stops. The supply of hydrogen peroxide should be taken always from a fresh bottle.

Yours, etc.,

N. C. MOITRA, м.в.

Houz Katra, Benares City :

8th August, 1919.

\section{THE DISINFECTION OF JAILS AND ASYLUMS} WITH CHLORINE SOLUTION.

To the Editor of THE Indian Medical GazeTTE.

SiR,-In view of the exhorbitant cost of cleansing the wards and cells of a large institution with phenyl and coal-tar derivatives (Rs. 30 to Rs. 40 per mensem), we have been compelled to carry out practical experiments with solutions of chlorine of different strengths. The results have been very good and most convincing.

Stock solutions have been prepared :- $(a)$ Chloride of lime $\frac{1}{2} 1 \mathrm{~b}$.; water $12 \mathrm{oz}$. Stir with a wooden rod for 15 minutes. Add water up to one gallon. (b) Soda ash $5 \mathrm{oz}$; ; water to one gallon. Dissolve.

Mix $(a)$ and $(b)$ and allow to settle overnight. Decant the clear solution (containing sodium hypochlorite) and store in bottles or jars in a cool, dark place. This solution contains about 1 per cent. available chlorine.

For use, it is diluted with water to 100 volumes $(0.01$ per cent. That chlorine is a disinfectant every one knows, but we were not so certain of its powers to deodorisela cell, whose walls, floor and bed had been covered with filth by its demented occupant. Our experiments were conducted and results compared by using parallel dilutions of phenyl and the following are the advantages :-

(1) Cost.-Disinfection of this institution by chlorine solution costs Rs. 4 per mensem, compared with Rs. 30 to Rs. 40 with coal-tar derivatives.

(2) Efficiency.-As a deodorant, chlorine solution is superior. The odour of a filthy room after cleansing with phenyl solution tends to " return" after a few hours, and this is not so when the other is used.

(3) Chlorine solution is more suitable than phenyl solution for washing filthy patients and much less apt to cause dermatitis.

(4) It is less poisonous than phenyl, which is a point of importance in an asylum.

I see no reason why chlorine solution should not supersede phenyl for use in regimental lines and latrines throughout India. The ingredients are obtainable, on the Bengal side, from the Bengal Chemical and Pharmaceutical Works, Calcutta.

\section{W. LEONARD FORSYTH, м.в.} Captain, I. M. S.,

Medical Supdt., Ranchi European Asylum

\section{THERAPEUTIC NOTES.}

\section{BRITISE SCIENTIFIC PRODUCTS EXHI BI rION, 1919.}

Medical Section.

THis Exhibition was held at the Central Hall, Westminster, from July 3rd to August 5th, to illustrate recent progress in British science and invention and to encourage the establishment and development of new British industries.

Burroughs, Weilicome \& Co.

Few practitioners are unaware of the important part played by Burroughs, Wellcome and Co., during the war, in the production of the fine chemicals, alkaloids and synthetics needed to replace those of German origin, upon which we were formerly so dependent.

A comprehensive array of this firm's contribution to the British fine chemical industry was a feature of the exhibit. A very wide range of medicaments was exhibited, of which phenacetin, acetylsalicylic acid (Empirin) sodium salicylate and 'Tolamine' are types.

In regard to the production of alkaloids, Burroughs, Wellcome and Co.'s record dates back long before the war. Twenty years ago they were producing on a commercial basis pilocarpine and its salts; atropine, eserine and homatropine followed; and to-day, products of the firm included in their exhibit were cocaine, hyoscine hydrobromide, sparteine sulphate, emetine hydrochloride, and many other alkaloids and alkaloidals salts.

The production of 'Kharsivan' and 'Neokharsivan' was a veritable triumph for British science and skill. These preparations completely superseded the German salvarsan and neosalvarsan, and the fact that they were placed at the disposal of the medical profession within a very short time of the outbreak of war illustrates how thoroughly and vigorously the necessary researches and investigations had been conducted by the firm's chemists.

Researches at the Wellcome Chemical Research laboratories, chosen for demonstration on this occasion, were those relating to hyoscine and its hydrolytic products, the resolution of these substances into their optically active components being diagrammatically illustrated, and specimens of the intermediate products shown.

Another section dealt with sodium gynocardate, and related substances. ' Special interest attaches to these preparations, on account of their utilisation in the treatment of leprosy.

A display illustrating investigations conducted in these laboratories into glyoxaline and alkaloids derived from it was also to be noted.

It was impossible to indicate in the exhibit more than a fraction of the work of this institution. The scope of its activities may be gathered from the fact that, during 